\title{
The Research on SMEs Loan Credit Insurance System of China
}

\author{
Ruilin Ren* \\ Guizhou University of Finance and Economics \\ Guiyang, China \\ 634569608@qq.com
}

\author{
Jianhua Zhu \\ Guizhou University of Finance and Economics \\ Guiyang, China \\ 948841731@qq.com
}

\begin{abstract}
China's SMEs are an integral part of the national economic system and have developed rapidly in recent years. However, the problem of financing difficulties for SMEs in China is highlighted, which hinders the sustainable development of SMEs. This paper analyzes the financing dilemma of China's SMEs and the importance of developing credit insurance system for SME loan. At the same time, it selects the listed companies in Shanghai and Shenzhen in 2016 as the sample analys is of the study, and proposes from the improvement of the company's own capabilities, credit environment optimization, risk monitoring advanced with the times, in order to provide a new way to solve the financing dilemma of SMEs.
\end{abstract}

Keywords-Credit insurance system; financing; LOGIT Method; small and medium enterprises

\section{INTRODUCTION}

Small and medium-sized enterprises are an important force for promoting the healthy and sustainable development of our national economy and the foundation and supporting force of large enterprises. According to the survey report, by the end of 2016, the number of small and medium-sized enterprises in our country was about 70 million, accounting for more than $99 \%$ of the total number of enterprises in China. The tax paid by these SMEs accounted for more than $50 \%$ of the total tax revenue, providing about $80 \%$ of the employment opportunities in cities and towns, and the value of import and export accounted for $70 \%$ of the total value. However, the financing process of China's SMEs has always been in a weak position under a difficult circumstance due to the dual constraints of external and internal factors. The financing gap and tax deficit make the operation of enterprises unbearable. The credit insurance system for small and medium-sized enterprises, established by the government, aims to promote and guide banks and other financial institutions to provide loans to small and medium-sized enterprises. It is specialized insurance institutions established by the government to provide insurance for banks to issue loans to small and medium-sized enterprises. When the borrowing enterprises fail to repay loan, the insurance institutions will give certain economic compensation to the loan banks for their losses. The purpose of setting up the credit insurance system for small and mediumsized enterprises is to share the risk that loans issued by banks to small and medium-sized enterprises and to guide banks to issue loans to small and medium-sized enterprises so as to promote the development of SMEs. This is an important

This project is supported by 2017 research project in itiated by insurance workstation of Guizhou University of Finance and Economics.

Project name: research on the credit insurance systemfor China's SMEs measure by the government to offer financial assistance to small and medium-sized enterprises. Therefore, the development of the credit insurance system for small and medium-sized enterprises can broaden the financing channels of small and medium-sized enterprises and relieve the financing pressure.

\section{THE IMPORTANCE OF DEVELOPING CREDIT INSURANCE SYSTEM FOR SMES IOAN}

\section{A. Expanding the business scope of insurance companies}

Develop loan insurance is a new attempt to promote cooperation between banking and insurance. Loan insurance enables credit risk to be distribute in the financial industry, and insurance companies gain a huge market from their commitment to insurable risk.Through the establishment of loan credit insurance, the insurance business can be extended and developed towards to the credit field, promoting diversification of the insurance business, expanding the coverage and service fields, accumulating more insurance funds, and strengthening the vitality of the insurance company.

\section{B. Improving the safety of bank assets}

It can effectively reduce the bank's operation risk. Credit risk (the operational risk commercial banks facing) refers to the possibility or uncertainty of losses suffered by the borrower due to the unreturnable principal and interest for loan on schedule, which is the main risk of China's commercial banks in the management. Establishing credit insurance system for small and medium-sized enterprises can effectively solve information asymmetry. Meanwhile, as banks and insurance companies are involved in the application for loans by enterprises, they strictly control credit funds based on their interests and responsibilities, strengthening the management of credit funds and reducing bank's operation risk to a certain extent.

\section{Strengthening the financing capacity of small and medium- sized enterprises}

First of all, insurance companies can provide commercial banks with financing insurance through business innovation and expansion and implant financing into SMEs to further reduce the risk of credit granting to SMEs, directly enhance the financing capability of SMEs so as to increase the indirect financing of SMEs. Secondly, developing credit insurance of bank loan can spread the credit risk brought by SMEs to broaden the financing channels of SMEs. Adopting insurance mechanism can effectively improve credit awareness of 
enterprise and improve the credit of SMEs. Banks and other financial institutions are willing to provide more funds to support the development of small and medium-sized enterprises, so that the availability of SMEs loan can be improved, that is, the external financing capacity is enhanced. Finally, developing credit insurance for loans can effectively solve information asymmetry, increase banks' understanding to SMEs' information, and provide better financial support. Once the financing problem of SMEs is relieved, enterprises can use funds more effectively for reproduction, enhancing profitability and improving inner-source financing capacity.

\section{RISK ANALYSIS ON LOAN CREDIT INSURANCE OF CHINA'S SMES}

In the logistic model, the event probability can be transformed into the probability that the explained variable with value of 1 , which happen to have the same view with the research content in this paper. In this paper, the dependent variable is a classified variable with values of 0 and 1 respectively. Since the research content of this paper is the credit risk of SMEs, we often need to assess and distinguish the credit status of enterprises when analyzing and regressing indicator data of enterprise by using logistic model.The credit status of enterprises is distinguished through whether they receive ST herein.Since dependent variable Y can only take the values of 0 and 1 , this paper also distinguishes the credit status of enterprises through whether they receive ST, so a conclusion can be made that if dependent variable $\mathrm{Y}$ takes the value of 0 , the enterprise has a good credit status and is not the one given ST; if dependent variable Y takes the value of 1 , the enterprise has a problem with credit status and is the one given ST.The specific analysis of logistic regression model involves the selection of a default demarcation point. Selection standard of different default demarcation point play a certain role in define the credit status of enterprises. In this paper, the break-even point is 0.5 , and $\mathrm{P}$ presents the event probability, where $\mathrm{p} \in$ $(0,1)$. If the value of $p$ is equal to or greater than 0.5 , it means that the probability of credit crisis of the evaluation company is relatively higher and can be determined as a enterprise with ST; If the value of $\mathrm{P}$ is less than 0.5 , it means that the probability of credit crisis of the evaluation company is relatively lower, and can be determined as an enterprise without ST. The function expression of Logistic model can be written as:
$\operatorname{Logit}(p)=\ln \left(\frac{p}{1-p}\right)=\beta_{0}+\beta_{1} \chi_{1}+\beta_{2} \chi_{2}+\cdots+\beta_{n} \chi_{n}$

Where, the value of $\mathrm{P}$ refers to the probability that financed SMEs with SP in this paper, namely the probability that they are given ST. X refers to the factor variable hereinafter, i refers to the number of factor variables, means the coefficient of explanatory variable $\mathrm{X}$, and refers to the constant term of empirical analysis.

The main advantage of Logit model is that it does not need to assume multivariate normality like discriminant analysis and has the same covariance matrix. However, it also has some defects in the estimation; for instance, the fundamental assumption of model is unreasonable and has no additivity. The distinguish on the intermediate section has strong sensibility, which leads to the instability of the discrimination result. This has to be paid attention to when using it.

\section{A. Data sources}

The sample selection can be divided into two types: normal companies and abnormal companies. This paper selects 2016 listed companies in Shanghai and Shenzhen as the research samples. After excluding the listed companies with missing data, 52 enterprises with ST and * ST remained. At the same time, it randomly selects 130 listed companies without ST as matched samples according to a certain proportion. All samples are divided into training samples and test samples based on the ratio of 7: 3, and the data in this paper are all from Resset Financial Research Database.

\section{B. Indicators selection}

Based on the credit rating indicators system of state-owned commercial banks and related indicators of related literatures at home and abroad, this paper selects 19 financial indicators. The selection basis is mainly from the following three aspects:

- data validity: selecting financial ratio that has important indicative functions for predicting the credit risk of enterprise

- comprehensiveness of data: fully reflecting the operating status and development ability of listed companies

- availability of data. Specific indicators are shown in TABLE I

TABLE I. ESTABLISHMENT OF INDICATORS SYSTEM

\begin{tabular}{|c|c|c|}
\hline Types & Indicators selection & Formula \\
\hline \multirow{5}{*}{ Debt solvency } & Liquidity ratio & current assets / current liabilities \\
\hline & Cash coverage ratio & net cash flow / current liabilities \\
\hline & Asset-liability ratio & total liabilities / total assets \\
\hline & Quick ratio & quick assets / current liabilities \\
\hline & Equity ratio & total liabilities / total owner's equity \\
\hline \multirow{6}{*}{ Profitability } & Operating income profit margin & net profit / total operating income \\
\hline & Return on assets & Pretax profit / average total assets \\
\hline & Net assets income rate & Net profit / stockholders' equity \\
\hline & Operating profit ratio & Operating profit / total operating income \\
\hline & Gross profit margin & Gross selling profit / net selling income \\
\hline & Net profit margin & net profit / net operating revenue \\
\hline \multirow{4}{*}{ Operation capacity } & Inventory turnover ratio & Operating cost / average inventory balance \\
\hline & Velocity of liquid assets & Net income from main business / average total current assets \\
\hline & Total assets turnover & Net operating income/ average total assets \\
\hline & Receivable turnover & operating income / average balances receivable \\
\hline
\end{tabular}




\begin{tabular}{|c|c|c|}
\hline \multicolumn{2}{|c|}{ Cont. to TABLE I } \\
\hline \multirow{4}{*}{ Growth ability } & Net profit growth rate & ( current net profit - previous net profit ) / previous net profit \\
\cline { 2 - 3 } & Total assets growth rate & total assets growth this year / total assets at the beginning \\
\cline { 2 - 3 } & Operating income growth ratio & $\begin{array}{c}\text { Current earnings pershare - previous earnings per share )/ previous earnings per } \\
\text { share }\end{array}$ \\
\cline { 2 - 3 } & Growth rate of earnings per share & \\
\hline
\end{tabular}

\section{Empirical analysis}

In the regression analysis, the variable selection adopts the Enter method (all variable forced entry), the probability demarcation point is 0.5 when model predicts, and namely the enterprise is the one with ST if the probability $\mathrm{P}$ is greater than 0.5 , while it is the one without ST if probability demarcation point is less than 0.5 . After introducing the common factor into regression analysis, the output results are shown in the following tables, in which table 3-2 is the test result of the overall manifestation of the regression model. It can be seen from the table that the measured value of likelihood ratio chisquared statistic is 161.826 ; the value of probability $\mathrm{p}$ is 0 . If the significant level is 0.05 , and the value of probability $\mathrm{p}$ is less than 0.05 , the original hypothesis that all regression coefficients are equal to zero should be rejected, but the model as a whole is significant.

TABLE II. EST ON SIGNIFICANCE OF THE MODEL AS A WHOLE

\begin{tabular}{|c|c|c|c|}
\hline & Chi-square & df & Sig. \\
\hline Steps & 161.826 & 18 & 0.000 \\
\hline Block & 161.826 & 18 & 0.000 \\
\hline Model & 161.826 & 18 & 0.000 \\
\hline
\end{tabular}

TABLIII shows the goodness-of-fit test for the evaluation model, in which log-likelihood value of - 2 is - 2 times of the log-likelihood function value, the smaller the value is, the higher that the goodness-of-fit of the regression model is, the closer Nagelkerke $\mathrm{R}$ square is to 1 , and the higher the goodness-of-fit is. From the analysis results, it can be seen that the log-likelihood of - 2 is very small, and Nagelkerke R square is 0.844 , which indicates that the model has good goodness-offit.

TABLE III. TEST ON GOODNESS-OF-FIT OF MODEL

\begin{tabular}{|c|c|c|}
\hline $\begin{array}{c}\text { Log-likelihood } \\
\text { value of }-2\end{array}$ & $\begin{array}{c}\text { Cox \& Snell R } \\
\text { square }\end{array}$ & $\begin{array}{c}\text { Nagelkerke R } \\
\text { square }\end{array}$ \\
\hline $55.944 a$ & 0.589 & 0.844 \\
\hline
\end{tabular}

According to misjudged matrix ( as shown inTABLEIV), among 182 companies, 2 of them were wrongly judged. A conclusion can be made that the overall prediction accuracy of the model is $94.5 \%$, and the prediction effect of the model is very ideal.

TABLE IV. MISJUDGED MATRIX

\begin{tabular}{|c|c|c|c|}
\hline \multirow[b]{3}{*}{ Observed } & \multicolumn{3}{|c|}{ Predicted } \\
\hline & \multicolumn{2}{|c|}{ ST or not } & \multirow{2}{*}{$\begin{array}{c}\text { Percentage } \\
\text { proofreading }\end{array}$} \\
\hline & 0 & 1 & \\
\hline ST or not & 127 & 3 & 97.7 \\
\hline $\begin{array}{l}0 \\
1\end{array}$ & 7 & 45 & 86.5 \\
\hline \multicolumn{3}{|c|}{ proportion of the total volume } & 94.5 \\
\hline
\end{tabular}

\section{Empirical results}

Through the introduction of relevant data on financial indicators of listed enterprises, this paper makes an empirical and quantitative analysis on the credit risk of SMEs by using the logistic model, and obtains relevant research results. We can see from the research and analysis results of the Logistic model:

- This paper uses Logistic model to make regression analysis on the established samples of the evaluation indicators system. From the output results of logistic model, we can see that the overall correct percentage of the model has reached $94.5 \%$, among which the correct prediction rate of the enterprises without ST reaches up to $97.7 \%$, and that of the enterprises with ST is $86.5 \%$. At the same time, relatively high prediction rate has also been obtained by using test samples, which shows that the prediction effect of the model is relatively ideal. Therefore, we can see that for the assessment on credit risk of SMEs made based on the model is effective.

- The greater the debt repayment factor is, the smaller the probability of the enterprise corporate and the credit risk are; the greater the profit factor, the smaller the probability of the enterprise corporate and the credit risk are. The debt repayment factor is greatly influenced by the liquidity ratio, cash ratio and quick ratio, while the profit factor is greatly influenced by the return on total assets, the rate of return from main business, the gross profit rate and the net profit rate. In fact, the higher the liquidity ratio, the cash ratio and the quick ratio are, the lower the credit risk of the enterprise is; the higher the return on total assets, the rate of return from main business, the gross profit rate and the net profit rate are, the lower the credit risk of the enterprise is, which is also in line with the actual situation. The greater turnover factor is, the smaller the probability of enterprise default is, the smaller the credit risk is, and so turnover factor is significantly influenced by velocity of liquid assets, inventory turnover rate and total assets turnover rate.

- As the constant increase of the default demarcation point, the overall prediction rate of the model shows the tendency rising up at the beginning and declining in late. The optimal value of default demarcation point is around 0.5 .

\section{CONCLUSIONS}

This paper analyzes the current status and difficulties of SMEs financing. Through empirical analysis on 182 small and medium-sized enterprises, the paper builds a credit risk evaluation model for SMEs, and makes regression analysis on the selected financial indicators by using Logit regression model. Based on the analysis results, this paper puts forward the following suggestions: 


\section{A. Strengthening the profitability and turnover of capital}

The assets value and profitability of the enterprise reflects the state between the assets invested by the enterprise and the actual investment profit. The higher profitability reflects effective utilization of funds, and the sufficient capital will directly improve the owner's rights and interests. Asset turnover can effectively measure capital intensity: high asset turnover level means low capital intensity and vice versa, so the enterprises can increase their income by improving the turnover management level of current assets and inventories. Therefore, SMEs can strengthen the profitability and turnover of capital to improve the loan approval rate.

\section{B. Strengthening enterprise scale and brand building}

The financing difficulties of SMEs in the credit market are partly because of the small size of the enterprises. Under normal circumstances, the scale of SMEs has a negative correlation with credit risk, that is, the larger the scale of SMEs is, the lower their credit risk is, and vice versa. Commercial banks will also hold a very cautious attitude towards such enterprises. Therefore, SMEs can expand their scale to reduce their credit risk and obtain credit support from banks. In addition, SMEs should also strengthen their own brand building, improving their popularity and establishing brand effect.

\section{Improving the social credit management system}

Establishment of the loan insurance system for SMEs requires a good credit environment and perfect credit investigation system of enterprise and individual and credit evaluation system. Strengthening the close cooperation among the departments of industry and commerce, taxation and justice, and gradually connecting the data of the financial sector with that of other departments so as to realize the information resources sharing and reduce the cost of credit information. At the same time, it requires to speed up the establishment and improve the credit rating system, and to give full play to the mutual benefit and mutual promotion between credit insurance and loan financing.

\section{Adjusting regulatory policies timely}

All financial supervision departments should adjust their supervision policies according to the actual condition. With the development of bank insurance, the combination between banking industry and insurance industry become closer. More and more cross businesses and alternative products will emerge, and both parties involved may also cooperate in the selection and use of certain financial instruments in the capital market in order to achieve special purpose. At the same time, credit insurance for SMEs loan is a new form of cooperation between banks and insurance companies, and has a high risk. These changes are likely to cause new financial problems. Therefore, financial supervision institutions have to adjust the supervision mode and contents in time to adapt to the development and changes of supervision targets, which promotes the business innovation and development between banks and insurance companies, on the other hand, effectively prevents risks caused by banks and insurance companies from spreading and avoids the financial chain crisis and even the entire social and economic crisis.

\section{REFERENCES}

[1] The research on financial failure prediction of SMEs by Liang Qi, Guo Xin wei, Shi Ning based on logistic model. [J]. Journal of Industrial Engineering and Engineering Management, 2014,2803: 126 - 134;(In Chinese)

[2] The research on credit risk of listed SMEs in China by Peng Wei based on empirical analysis of logistic model. [J]. Financial Regulation Research, 2012,01: 101 - 116; (In Chinese)

[3] The study on credit risk measurement of commercial banks based on primary content analysis and Logit model by Zhang Chuanxin, Wang Guangwei. [J]. West Forum on Economy and Managemen, 2012,2304: $17-23+57 ;$ (In Chinese)

[4] The financial crisis early warning model design and empirical research for SMEs by Xu Yufang, Shao Shenghua. [J]. Friends of Accounting, 2017,12: 31 - 34;(In Chinese)

[5] Empirical test on influence factors on over-guarantee of SMEs by $\mathrm{Xu}$ Pan, Pan Yushuang. - based on analysis of logistic model [J]. Finance and Accounting Monthly, 2016,12: 60 - 65;(In Chinese)

[6] The research on credit risk evaluation of SMEs based on supply chain finance by Qiu Wei, Zhang Jiantong. [J]. Shanghai Management Science, 2016,3804: 46 - 50;(In Chinese) 